Rocky Mountains (Figure 1, Sherwood 2013). We used a replicated block design of snow removal (SR) and passive heating $(\mathrm{H}+)$, both treatments ( $\mathrm{SR}$ and $\mathrm{H}+$ ) and a control (CT) to examine the effects of temperature, snow removal and their potential interactions on soil conditions, plant growth, and insect responses. In 2014 we added a new dimension: assessing how snow removal and warming affect nectar resources for pollinators. Our hypothesis was that reduced soil moisture from reduced snowpack and passive heating would be correlated with lower nectar volume and/or sugar content in nectar plants.

\section{$\downarrow$ MeTHODS}

\section{Study organisms and study site}

The study area for this study is a sagebrush (Artemisia sp.) meadow at an elevation of 2100 meters. This area has relatively flat, homogeneous topography and is located in Grand Teton National Park, WY. The meadow is approximately $2 \times 0.5 \mathrm{~km}$ in size (Auckland et al. 2004) and is just south of the University of Wyoming-National Park Service Research Station, where our research team is housed during the field season. For this project, we monitored Balsamhoriza sagitata (Arrowleaf Balsamroot, below left) and Eriogonum umbellatum (Wild Buckwheat, below right). These two nectar resources are particularly valuable to the butterfly Parnassius clodius (butterfly in photo at right) found within this system.

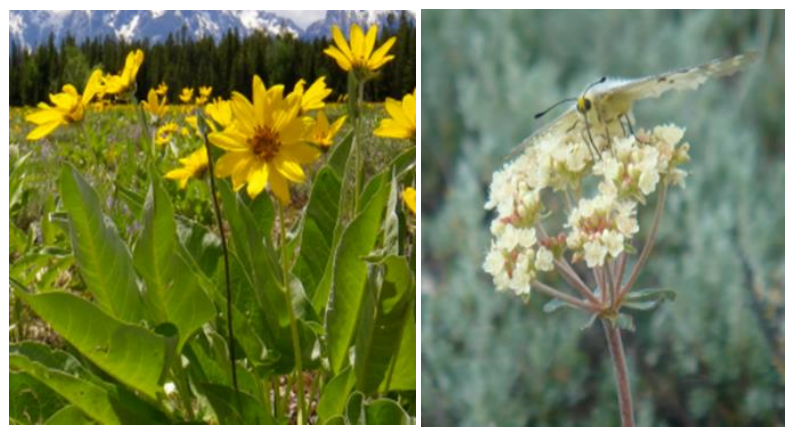

Field methods

The experimental design includes three replicated blocks of four $2.5 \times 2.5 \mathrm{~m}$ plots with the following treatments: snow removal (SR), passive heating $(\mathrm{H}+)$, both treatments ( $\mathrm{SR}$ and $\mathrm{H}+$ ) and control (CT). Each plot is separated by $5 \mathrm{~m}$ and is laid out in a regular pattern within the meadow. The plots were set up in 2010, with landscape edging buried to delineate plot edges.
Snow is removed manually using shovels at the end of April/early May. Assuming $53 \mathrm{~cm} / \mathrm{yr}$ of precipitation (Shaw 1958), mostly as snow, with a spring snowpack that is about $50 \%$ water by volume (California Department of Water Resources [n.d.]), removing $50 \mathrm{~cm}$ of the snowpack (i.e., all snow still present in early May) can reduce the annual precipitation by approximately one half. As we have developed these techniques, we have determined that snow depth should be maintained at $\sim 2 \mathrm{~cm}$ in treatment plots to minimize the possibility of vegetation damage. New or wind-driven snow is removed when present after the initial snow removal. Snow depth in control plots is also measured and recorded during the sampling period.

We utilized a louvered Open-Sided Chamber (OSC, Figure 1) to warm our plots, placed on the site when snow is removed in late April/early May and left there through the growing season. OSC's passively increase the downwelling infrared (longwave, or thermal) radiation to plant and soil surfaces, thereby increasing minimum nighttime temperatures by several degrees Celsius (Germino and Smith 1999). There are a variety of both active (e.g., infrared lamps or heating cables) and passive (e.g., open-top chambers, shelters, or covers) methods available for creating warming conditions (Kennedy 1994, Convey and Wynn-Williams 2002, Bokhurst, et al. 2008). Each method has advantages and disadvantages for changing light or moisture regimes or altering of wind patterns or atmospheric exposure (Beier et al. 2004), and most of these approaches have been used to increase maximum daily temperatures (i.e., Kennedy 1994, Convey and Wynn-Williams 2002, Bokhurst, et al. 2008). It is important to evaluate ways to experimentally simulate increased minimum temperatures given that the daily minimum temperatures are increasing faster than daily maximum temperatures (Kukla et al. 1994, Alward et al. 1999).

Temperature and soil moisture are measured and recorded at $25 \mathrm{~cm}$ depth using soil moisture meters buried in the soil (Sherwood 2013). Debinski (unpublished data) showed that snow removal in early May can affect soil moisture at $25 \mathrm{~cm}$ depth through the growing season. Dataloggers record daily at 12:00 hrs through the summer.

\section{Extracting nectar}

During the flowering season, nectar was collected from each plant within the plot as it reached peak flowering time. We extracted the nectar using 
icrocapillary pipettes, placed into the flower where the nectar pools. Once the nectar was extracted from the flower, we measured the length (in $\mathrm{mm}$ ) of nectar within the tube, the size of the microcapillary pipet, and the temperature and relative humidity. We used a refractometer (with a Brix scale). Because buckwheat has very small flowers, we pooled samples from five flowers.

\section{Calculating nectar volume}

Nectar volume was calculated using the following equation:

$$
\begin{gathered}
\text { microcap size }(\mu L) * \frac{\text { mm of nectar in pipet }}{\text { mm length of pipet }} \\
=\text { Volume of nectar }(\mu L)
\end{gathered}
$$

\section{Determining sugar concentration}

We converted the percent sucrose (Brix value) to concentration of sugar $(\mathrm{mg} / \mathrm{mL})$ (Kearns and Inouye 1993). Nectar sugar concentration is calculated using the following equation:

$$
\begin{array}{r}
\text { Nectar volume }(\mu L) * \text { concentration of sugar }\left(\frac{m g}{m L}\right) \\
* \frac{1 m L}{1000 \mu L}=\text { Amount of Sugar }
\end{array}
$$

\section{$\uparrow \quad$ RESUlTS}

We compared both nectar volume and sugar content of each plant species relative to treatment (Tables 1 and 2). Preliminary analysis show that for Eriogonum umbellatum nectar volume was lower in the heating compared to either the control or snow removal and that heating and snow removal was also lower than snow removal only. The sugar amount did not show much variation among treatments. For Balsamorhiza sagittata there were no differences among treatments in the nectar volume, but there were differences in the sugar amount. Preliminary results show that the control was lower in sugar volume than the heating + snow removal.

\section{CONCLUSIONS}

These data show that there could be changes in nectar resources associated with warming and/or reduced snowpack. They also show that the responses could vary among plant species. Such changes could have important implications for the pollinator

\begin{tabular}{|c|c|c|c|c|}
\hline \multirow[b]{2}{*}{ Treatment } & \multicolumn{2}{|c|}{ 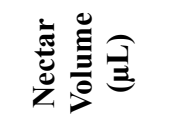 } & \multicolumn{2}{|c|}{ 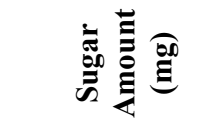 } \\
\hline & 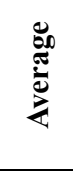 & 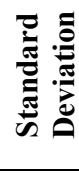 & 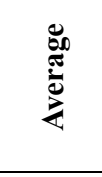 & 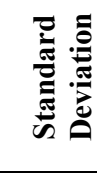 \\
\hline Control $(n=54)$ & 0.68 & 0.46 & 344.66 & 169.07 \\
\hline Heating $(n=60)$ & 0.52 & 0.22 & 335.90 & 131.16 \\
\hline $\begin{array}{l}\text { Snow Removal } \\
(\mathrm{n}=57) \\
\text { Heating + Snow } \\
\text { Removal } \\
(\mathrm{n}=57)\end{array}$ & 0.75 & 0.57 & 401.25 & 323.42 \\
\hline
\end{tabular}
community in Grand Teton National Park.
Table 1. 2014 GTNP nectar results: Sulphur Buckwheat (Eriogonum umbellatum)

Table 2. 2014 GTNP nectar results: Arrow-leaved Balsamroot (Balsamorhiza sagittata)

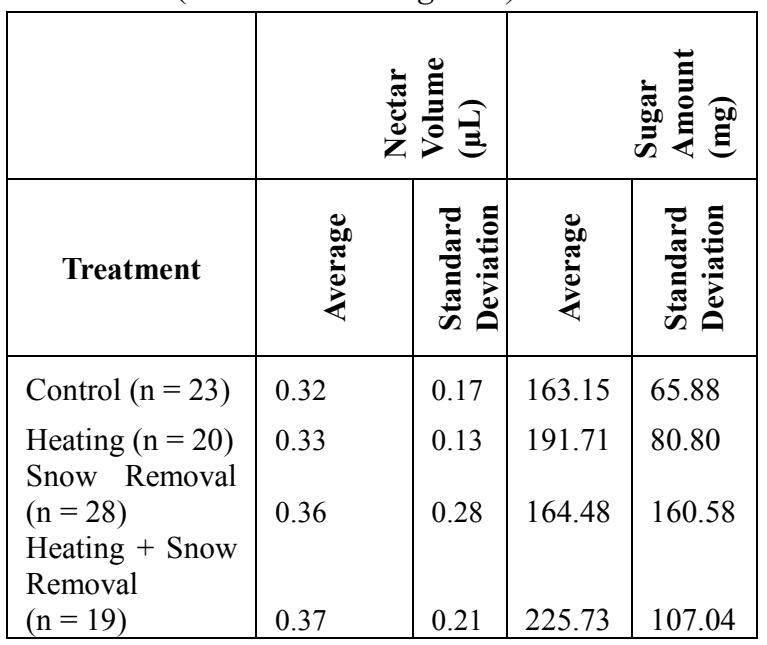

\section{$\downarrow \quad$ Literature Cited}

Adam, J. C., A. F. Hamlet, and D. P. Lettenmaier. 2009. Implications of global climate change for snowmelt hydrology in the twenty-first century. Hydrological Processes 23(7): 962.

Alward, R. D., J. K. Detling, and D. G. Milchunas. 1999. Grassland vegetation changes and nocturnal global warming. Science 283(5399): 229-231. 
Auckland, J. N., D. M. Debinski, and W. R. Clark. 2004. Survival, movement, and resource use of the butterfly Parnassius clodius. Ecological Entomology 29(2): 139-149.

Beier, C., et al. 2004. Novel approaches to study climate change effects on terrestrial ecosystems in the field: Drought and passive nighttime warming. Ecosystems 7(6):583597.

Bokhorst S., J. W. Bjerke, F. W. Bowles, J. Melillo, T. V. Callaghan, and G.K. Phoenix. 2008. Impacts of extreme winter warming in the sub-Arctic: Growing season responses of dwarf shrub heathland. Global Change Biology 14: 2603-2612.

California Department of Water Resources. [n.d.]. Depth and Density. Online at: http://cdec.water.ca.gov/ snow/misc/density.html. Accessed: October 2009.

Convey, P., and D. D. Wynn-Williams. 2002. Antarctic soil nematode response to artificial climate amelioration. European Journal of Soil Biology 38(3): 255-259.

Cubasch, U., et al. 2001. Projections of future climate change. Pages 526-582 In: J. T. Houghton, Y. Ding, D. J. Griggs, M. Noguer, P. J. Van der Linden, X. Dai, K. Maskell, and C. A. Johnson (eds.). Climate Change 2001: The Scientific Basis: Contribution of Working Group I to the Third Assessment Report of the Intergovernmental Panel.

Germino, M. J., and W. K. Smith. 1999. Sky exposure, crown architecture, and low-temperature photoinhibition in conifer seedlings at alpine treeline. Plant, Cell and Environment 22(4): 407-415.

Harte, J., and R. Shaw. 1995. Shifting dominance within a montane vegetation community: Results of a climate-warming experiment. Science 267(5199): 876-880.

Field C. B., V. R. Barros, D. J. Dokken, K.J. Mach, M. D. Mastrandrea, T. E. Bilir, M. Chatterjee, K. L. Ebi, Y. O. Estrada, R. C. Genova, B. Girma, E. S. Kissel, A. N. Levy, S. MacCracken, P. R. Mastrandrea, and L. L. White. 2014. Climate Change 2014: Impacts, Adaptation, and Vulnerability. Part A: Global and Sectoral Aspects. Contribution of Working Group II to the Fifth Assessment Report of the Intergovernmental Panel on Climate Change (IPCC). Cambridge University Press, Cambridge, United Kingdom and New York, NY, USA, 1132 pp.
Kearns, C. A., and D. W. Inouye. 1993. Techniques for Pollination Biologists. University Press of Colorado, Niwot, CO.

Kennedy, A.D. 1994. Simulated climate-change: A field manipulation study of polar microarthropod community response to global warming. Ecography 17:131-40

Kim, J., T. K. Kim, R. W. Arritt, and N. L. Miller. 2002. Impacts of increased atmospheric $\mathrm{CO} 2$ on the hydroclimate of the western United States. Journal of Climate 15:1926-1942.

Kukla G., T. R. Karl, and M. Riches (eds). 1994. Asymmetric Change of Daily Temperature Range, Proceedings of the International MINIMAX WORKSHOP, College Park, MD, 27 to 30 September 1993. U.S. Department of Energy, Washington, DC.

Notaro, M., Z. Liu, and J.W. Williams. 2006. Observed vegetation climate feedbacks in the United States. Journal of Climate 19:763-786.

Reiners, W. A., W. L. Baker, J. S. Baron, D. M. Debinski, S. A. Elias, D. B. Fagre, J. S. Findley, L. O. Mearns, D. Roberts, T. R. Seastedt, T. J. Stohlgren, T. T. Veblen, and F. H. Wagner. 2003. Natural Ecosystems 1. The Rocky Mountains. In: F. Wagner, and $\mathrm{T}$. Stohlgren (eds.). Preparing for a Changing Climate: The Potential Consequences of Climate Variability and Change. Rocky Mountain/Great Basin. A report of the Rocky Mountain/Great Basin Regional Assessment Team for the U.S. Global Change Research Program. Utah State Press. $455 \mathrm{pp}$.

Saunders, S., C. Montgomery, T. Easley, and T. Spencer. 2008. Hotter and drier: The west's changed climate. Rocky Mountain Climate Organization and the Natural Resources Defense Council, New York, NY. 54 pp.

Shaw, R. J. 1958. Vascular plants of Grand Teton National Park. American Midland Naturalist 59:146-166.

Sherwood, J.A. 2013. Experimentally simulating environmental change in a montane meadowsystem via reduced snowpack and passive warming: Soil and plant responses. M.S Thesis. Iowa State University.

Sherwood, J. A., D. M. Debinski, P. C. Caragea, R. Fahrenholtz, and M. Germino. In prep. Experimentally simulating climate change in a montane meadow system via reduced snowpack and passive warming: Soil and plant responses. To be submitted to Ecological Applications. 
Thuiller, W., S. Lavorel, M. B. Araujo, M. T. Sykes, and I. C. Prentice. 2005. Climate change threats to plant diversity in Europe. Proceedings of the National Academy of Sciences 102(23):8245 - 8250.
Zimmerman, G., C. O’Brady, and B. Hurlbutt. 2006. Climate Change: Modeling a Warmer Rockies and Assessing the Implications. Colorado College State of the Rockies Report Card. 